\title{
New records of Gerridae (Insecta, Hemiptera, Heteroptera) from northern South America
}

\author{
Irina Morales $^{1 *}$, Silvia P. Mondragón-F. ${ }^{1}$, Felipe Ferraz Figueiredo Moreira ${ }^{2}$ \\ 1 Laboratorio de Entomología, Universidad Pedagógica y Tecnológica de Colombia, Tunja, Boyacá, Colombia • IM: irina.morales@uptc.edu.co \\ (1) https://orcid.org/0000-0003-2456-5674 • SPMF: patriciamondragon18@gmail.com (1) https://orcid.org/0000-0001-6730-1535 \\ 2 Laboratorio de Biodiversidade Entomológica, Instituto Oswaldo Cruz, Fundação Oswaldo Cruz, Rio de Janeiro, Rio de Janeiro, Brazil • \\ ppmeiameiameia@gmail.com (D https://orcid.org/0000-0002-6692-0323 \\ * Corresponding author
}

\begin{abstract}
Based on material deposited in a Colombian entomological collection, new records from northern South America (Colombia and Venezuela) are presented for eight species of Gerridae (Insecta, Hemiptera, Heteroptera). The species belong to the genera Brachymetra Mayr, 1865 (Charmatometrinae); Limnogonus Stål, 1868; Neogerris Matsumura, 1913 (Gerrinae, Gerrini); Tachygerris Drake, 1957 (Gerrinae, Tachygerrini); Metrobates Uhler, 1871 (Trepobatinae, Metrobatini); and Telmatometra Bergroth, 1908 (Trepobatinae, Trepobatini). Photographs of the habitus of adults and distribution maps are also presented for each species.
\end{abstract}

\section{Keywords}

Aquatic insects, geographic distribution, Gerromorpha, Neotropical Region

\section{Introduction}

Among the aquatic insects, water striders of the family Gerridae (Hemiptera, Heteroptera, Gerromorpha) occupy a wide variety of habitats. They are usually found in streams, rivers, and lakes and are specialized in inhabiting the surface of the water (Andersen 1982). The family Gerridae is divided into eight subfamilies, of which two (Eotrechinae and Ptilomerinae) are absent from the Neotropical Region (Moreira 2015). In the Neotropics, there is a lack of knowledge concerning the geographical distribution of most taxa, and many areas are poorly explored, so the publication of new records and lists of species is fundamental (Moreira et al. 2016).

Recent studies on the Gerridae from Colombia show an increasing interest in the taxonomy and diversity of the family locally, including the description of new species (e.g., Mondragón-F. et al. 2017; Molano et al. 2017a, 2017b, 2018; Floriano et al. 2019), new distribution records (e.g., Padilla-Gil 2017), and regional surveys (e.g., Moreno et al. 2018). Unfortunately, the same is not true for Venezuela, where only a few studies concerning the family have been published so far, mostly restricted to old species descriptions (e.g., Drake and Roze 1954) or 

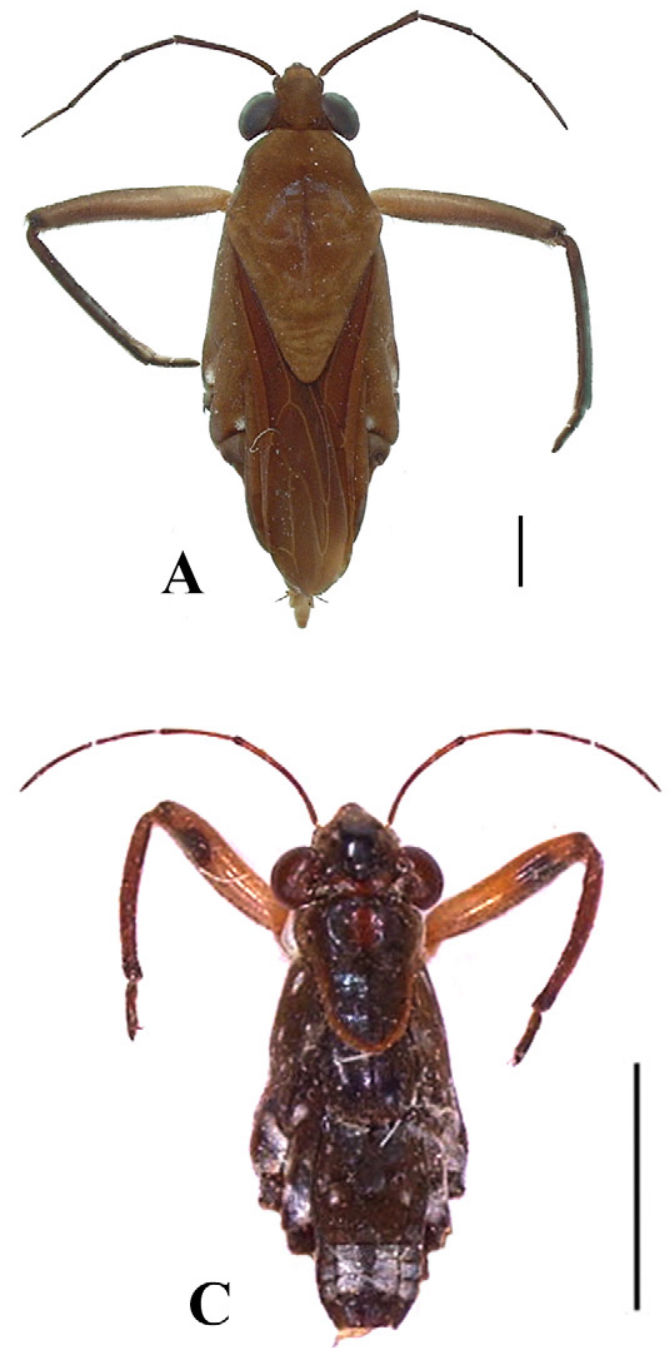
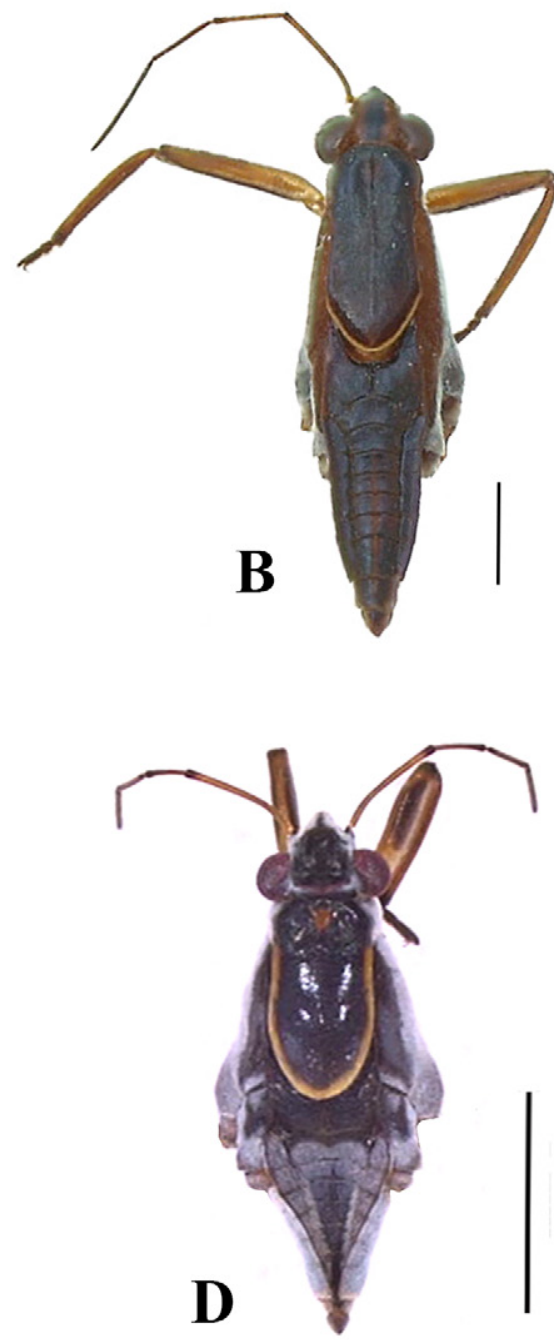

Figure 1. Habitus, dorsal view. A. Brachymetra shawi. B. Limnogonus ignotus. C. Neogerris lotus. D. Neogerris lubricus.

new records in a more general context (e.g., Moreira et al. 2016).

Considering this scenario, we present here new records from Colombia and Venezuela for eight species of Gerridae belonging to the genera Brachymetra Mayr, 1865 (Charmatometrinae); Limnogonus Stål, 1868; Neogerris Matsumura, 1913 (Gerrinae, Gerrini); Tachygerris Drake, 1957 (Gerrinae, Tachygerrini); Metrobates Uhler, 1871 (Trepobatinae, Metrobatini); Trepobates Uhler, 1894; and Telmatometra Bergroth, 1908 (Trepobatinae, Trepobatini).

\section{Methods}

Specimens examined are deposited in the Colección de Insectos, Museo de Historia Natural "Luis Gonzalo Andrade", Universidad Pedagógica y Tecnológica de Colombia, Tunja, Colombia (UPTC). Literature used for specimen identification is presented in the results under each species. The geographic distribution and the map of each species are based on the literature (e.g., Drake and Roze 1954; Nieser 1970, 1993; Molano et al. 2005; Morales and Molano 2009; Moreira et al. 2011, 2016;
Cordeiro and Moreira 2015; Floriano et al. 2017) and the labels of the material examined. Photographs were made using specimens preserved in alcohol and a Leica S9I stereomicroscope with integrated camera. Maps were produced using QGIS v. 3.20 (QGIS Development Team 2020).

\section{Results}

Subfamily Charmatometrinae

\section{Brachymetra shawi Hungerford \& Matsuda, 1957}

Figures 1A, 3

New records. VENEZUELA - Apure • ca. 6 km S. Río Cinaruco; 06.5150, -067.5434; $68 \mathrm{~m}$ alt.; 08.I.2006; L. García leg.; remanso [backwater], morichal [moriche palm plantation]; $1 \hat{\jmath}, 6$ + , UPTC-In-04766.

Identification. The specimens of $B$. shawi were recognized by the unmarked pronotum, which reaches at least the abdominal mediotergite I and is narrowly rounded at the apex in winged forms; the forewings reddishbrown, darker than the pronotum, with yellow veins; and the venter of male pygophore with a distinct notch at the 

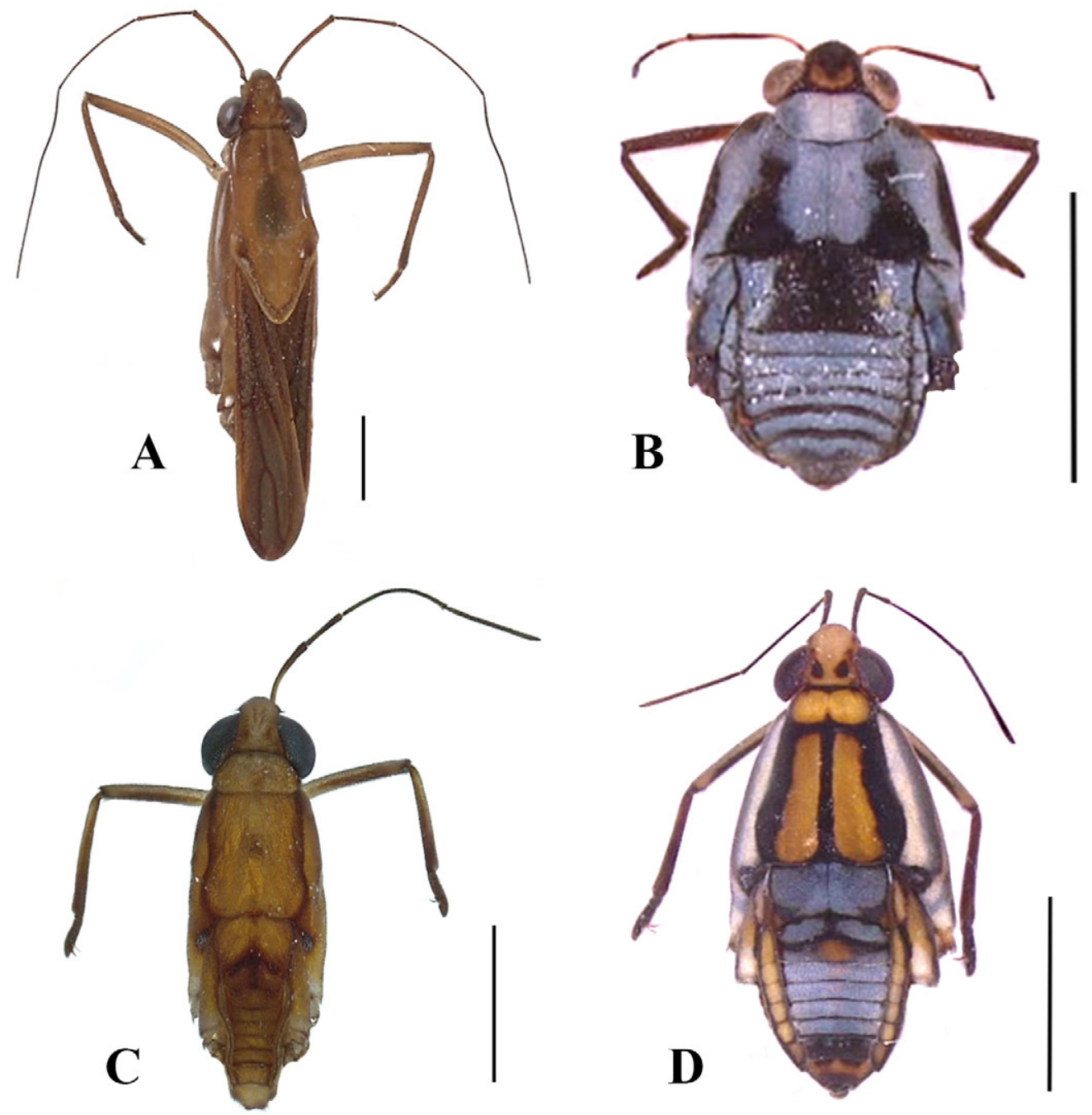

Figure 2. Habitus, dorsal view. A. Tachygerris tucanensis. B. Metrobates amblydonti. C. Telmatometra indentata. D. Telmatometra ujhelyii.

middle of the posterior margin (Cordeiro 2017).

Distribution. BOLIVIA (Hungerford and Matsuda 1957). BRAZIL (Nieser 1970). COLOMBIA: Putumayo (Padilla-Gil 2019), Vaupés (Morales and Castro 2010). FRENCH GUIANA (Hungerford and Matsuda 1957). GUYANA (Shaw 1933). SURINAME (Hungerford and Matsuda 1957). TRINIDAD \& TOBAGO (Nieser and Alkins-Koo 1991). VENEZUELA: Apure (this work).

Subfamily Gerrinae

Tribe Gerrini

Limnogonus ignotus Drake \& Harris, 1934 Figures 1B, 4

New records. VENEZUELA - Apure • ca. 6 km S. Río Cinaruco; 06.5150, -067.5434; $68 \mathrm{~m}$ alt.; 08.I.2006; L. García leg.; remanso [backwater], morichal [moriche palm plantation]; $4 \hat{\jmath}, 2$, , UPTC-In-04917.

Identification. This species was recognized by the antennomere I shorter than the width of the head through the eyes and the reddish-brown color along the dorsal portion of the mesopleuron (Nieser 1970; Molano et al. 2017a).
Distribution. ARGENTINA (Bachmann 1966). BOLIVIA (Kuitert 1942). BRAZIL (Drake and Harris 1934). COLOMBIA: Meta (Aristizábal-García 2002), Valle del Cauca (Posso and González 2008; Aristizábal-García 2017). FRENCH GUIANA (Motta et al. 2018). GUYANA (Drake and Harris 1934). PARAGUAY (Drake and Harris 1934). PERU (Kuitert 1942). SURINAME (Nieser 1970). URUGUAY (Bachmann 1964). VENEZUELA: Apure (this work).

\section{Neogerris lotus (White 1879)}

Figures 1C, 5

New records. VENEZUELA - Apure • ca. 6 km S. Río Cinaruco; 06.5150, -067.5434; $68 \mathrm{~m}$ alt.; 08.I.2006; L. García leg.; remanso [backwater], morichal [moriche palm plantation]; 3 , , UPTC-In-04562 • same collection data as for preceding; 1 , UPTC-In-04820.

Identification. Our female specimens were identified based on the short and globose eyes; the apterous pronotum relatively short, reaching slightly beyond half-length of the mesonotum; and the fore femur displaying an ovate spot on its lateral surface (Moreira et al. 2011). 


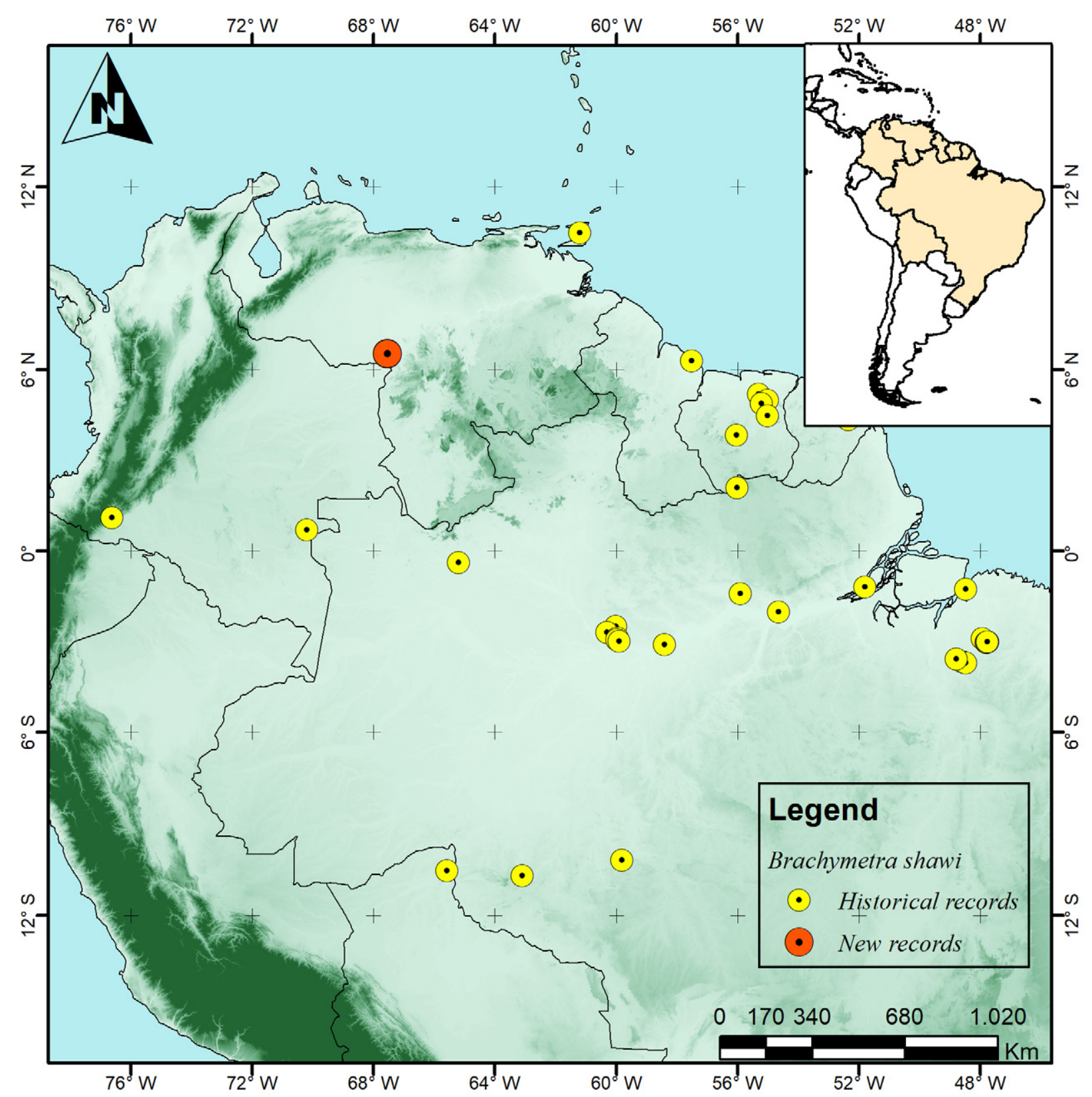

Figure 3. Historical and new records of Brachymetra shawi in the Americas.

Distribution. BRAZIL (White 1879). COLOMBIA: Caquetá (Molano et al. 2008), Casanare (Aristizábal-García 2017), Meta (Aristizábal-García 2002, 2017), Santander (Molano et al. 2005), Vaupés (Morales and Castro 2010). GUYANA (Kuitert 1942). PERU (Drake and Harris 1935). SURINAME (Nieser 1970). TRINIDAD \& TOBAGO (Nieser 1994). VENEZUELA: Apure (this work).

\section{Neogerris lubricus (White 1879)}

Figures 1D, 6

New records. VENEZUELA - Apure • ca. 6 km S. Río Cinaruco; 06.5150, -067.5434; 68 m alt.; 08.I.2006; L. García leg.; remanso [backwater], morichal [moriche palm plantation]; 2 ก, 2 q, UPTC-In-04822.

Identification. Our specimens of $N$. lubricus differ from $N$. lotus by the flatter eye; the apterous pronotum long, almost reaching the metanotum; and the fore femur with a brownish mark occupying most of its distal half (Moreira et al. 2011).

Distribution. ARGENTINA (Bachmann 1962). BOLIVIA (Kuitert 1942). BRAZIL (White 1879). COLOMBIA: Bolívar (Nieser 1994, Aristizábal-García 2002), Caquetá (Molano et al. 2008), Casanare (AristizábalGarcía 2017), Cesar (Morales et al. 2008; AristizábalGarcía 2017), Magdalena (Aristizábal-García 2017), Meta (Roback and Nieser 1974), Santander (Aristizábal-García 2002), Tolima (Aristizábal-García 2002). COSTA RICA (Pacheco-Chaves et al. 2018). ECUADOR (Aristizábal-García 2002). FRENCH GUIANA (Motta et al. 2018). GUYANA (Kuitert 1942). PANAMA (Matsuda 1961). PARAGUAY (Mazzucconi and Bachmann 1993). PERU (Kuitert 1942). SURINAME (Nieser 1970). TRINIDAD \& TOBAGO (Nieser 1994). VENEZUELA: Apure (this work). 


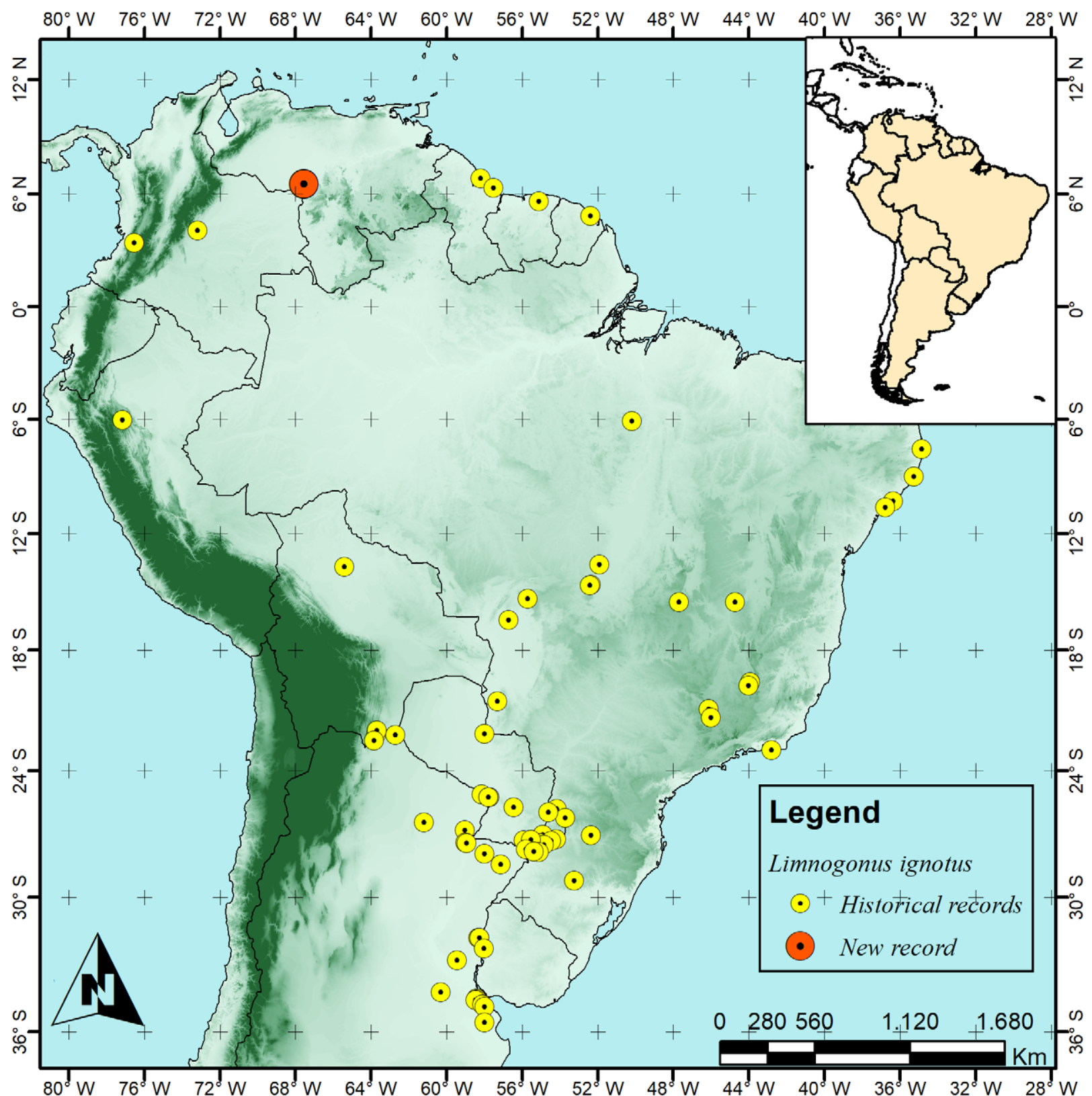

Figure 4. Historical and new records of Limnogonus ignotus in the Americas.

\section{Subfamily Gerrinae}

Tribe Tachygerrini

\section{Tachygerris tucanensis Morales \& Castro, 2013}

Figures 2A, 7

New records. VENEZUELA - Amazonas • Tobogán de la Selva, ca. $40 \mathrm{~km} \mathrm{~S}$. Puerto Ayacucho; 05.3875, -067.6176; 05.I.2006; L. García leg.; 2 ふै, 1 , UPTCIn-05221 - same collection data as for preceding; 1 ô, UPTC-In-05224 • Autana, Tobogán de la Selva; 05.3875, -067.6176; 05.I.2006; L. García leg.; 1 \%, UPTC-In-05222.

Identification. The males above were identified based on the small knob covered by short setae on the ventral margin of the fore femur; the broad, boat-shaped pygophore; and the slender, heart-shaped proctiger. The females display a short posterior projection on the last abdominal laterotergite (= connexival spine); and the posterior margin of abdominal sternum VIII protruding, slightly exceeding the posterior projections of the laterotergites, with three small lobes (Morales and Castro 2013).

Distribution. COLOMBIA: Amazonas (Mondragón-F. et al. 2017), Boyacá (Mondragón-F. et al. 2017), Cauca (Mondragón-F. et al. 2017), Vaupés (Morales and Castro 2013). VENEZUELA: Amazonas (this work).

Subfamily Trepobatinae

Tribe Metrobatini

\section{Metrobates amblydonti Nieser, 1993}

Figures 2B, 8

New records. VENEZUELA - Guárico - Ortíz, vía Dos Caminos-San Juan de los Morros; 9.4571, -67.1675; 09.I.2006; L. García leg.; 4 ふ઼, 3 ९, UPTC-In-04951. 


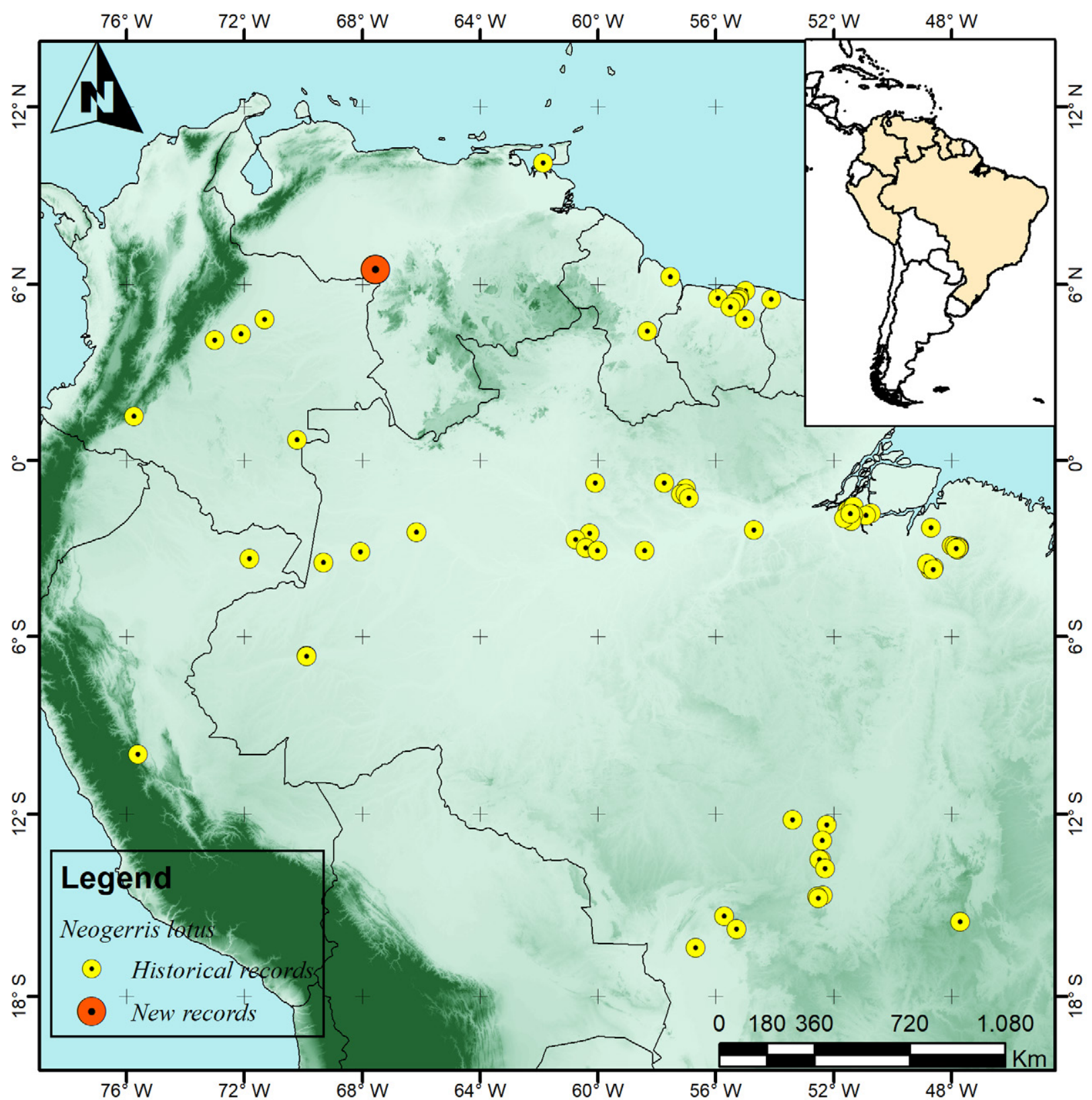

Figure 5. Historical and new records of Neogerris lotus in the Americas.

Identification. Our material was identified based on the head black with a V-shaped, reddish-brown interocular stripe; the antennomere I slightly narrowed basally; and the male paramere arcuate, broadly widened medially, apically with the dorsal margin curved then ending straight and the ventral margin straight (Castro et al. 2018).

Distribution. COLOMBIA: Amazonas (AristizábalGarcía 2002, 2017), Antioquia (Aristizábal-García 2002, 2017; Castro et al. 2018), Caquetá (Castro et al. 2018), Casanare (Aristizábal-García 2002, 2017), Cauca (Castro et al. 2018), Cesar (Aristizábal-García 2002, 2017), Córdoba (Aristizábal-García 2002, 2017), La Guajira (Castro et al. 2018), Norte de Santander (AristizábalGarcía 2002, 2017), Putumayo (Padilla-Gil 2013), Quindío (Castro et al. 2018), Risaralda (Castro et al. 2018), Valle del Cauca (Posso and González 2008; Cas- tro et al. 2018), Vichada (Aristizábal-García 2002, 2017). TRINIDAD \& TOBAGO (Nieser 1993). VENEZUELA: Guárico (this work).

Tribe Trepobatini

\section{Telmatometra indentata Kenaga, 1941}

Figures 2C, 9

New records. COLOMBIA - Caldas - Norcasia, Río Manso; 05.6642, -074.7823; 04.IV.2017; Orrego \& C. Llano leg.; 1 đ̃, 4 q, UPTC-In-05068.

Identification. Our specimens were identified based on the reddish-amber body; the mesonotum laterally with two parallel longitudinal stripes; the metanotum with a dark median mark reaching the posterior margin and meeting a dark transverse mark; the male abdominal segment VIII ventrally emarginated, the emargination 


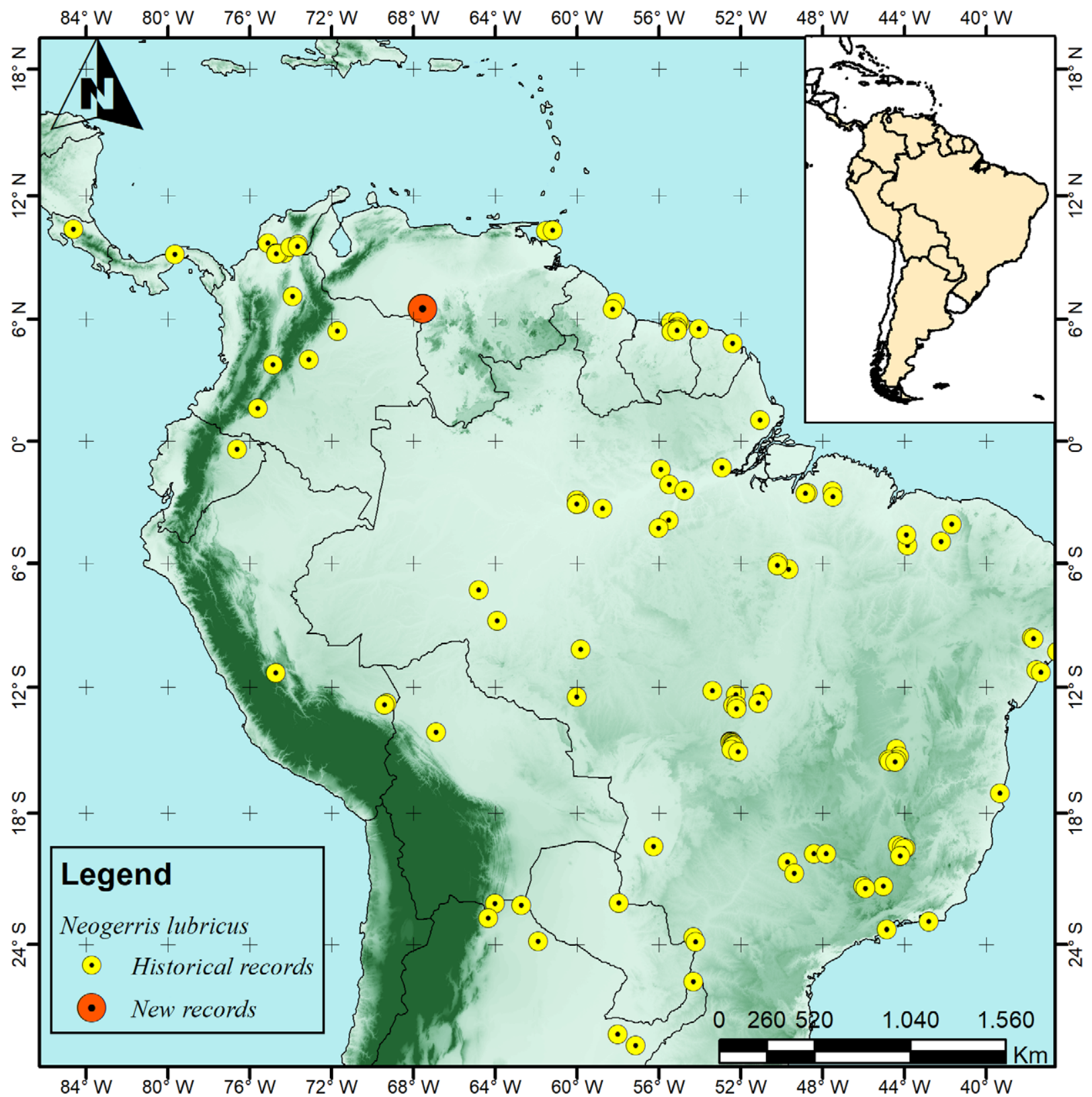

Figure 6. Historical and new records of Neogerris lubricus in the Americas.

V-shaped and reaching the posterior margin of abdominal sternum VII (Kenaga 1941); and the shape of the male paramere that matches Kenaga (1941: plate XII, fig. 2b).

Distribution. BOLIVIA (Kenaga 1941). COLOMBIA: Caldas (this work).

\section{Telmatometra ujhelyii Esaki, 1937}

Figures 2D, 10

New records. VENEZUELA - Zulia - Machiques, Toromo, Río Negro; 10.0296, -072.4262; $432 \mathrm{~m}$ alt.; 31. XII.2006; L. García leg.; 1 \&, UPTC-In-05050.

Identification. Our female specimen was recognized by the pronotum without longitudinal dark marks; and the mesonotum with the anterior margin black and all longitudinal stripes reaching the posterior margin (Molano et al. 2017b; Moreno et al. 2018).

Distribution. BELIZE (Kenaga 1941). COLOMBIA:
Antioquia (Aristizábal-García 2002, 2017), Caquetá (Molano et al. 2005), Casanare (Aristizábal-García 2002), Cesar (Aristizábal-García 2002, 2017), Chocó (Morales and Castro 2010), Córdoba (Aristizábal-García 2002, 2017), Cundinamarca (Aristizábal-García 2002, 2017), La Guajira (Aristizábal-García 2002), Magdalena (Esaki 1926; Aristizábal-García 2002), Meta (Morales and Castro 2010; Aristizábal-García 2017), Norte de Santander (Aristizábal-García 2002), Risaralda (Aristizábal-García 2002), Santander (Aristizábal-García 2002, 2017), Sucre (Aristizábal-García 2002, 2017; Moreno et al. 2018), Tolima (Aristizábal-García 2002), Valle del Cauca (Aristizábal-García 2002; Molano et al. 2008; Posso and González 2008). COSTA RICA (Pacheco-Chaves et al. 2018). ECUADOR (Buzzetti and Cianferoni 2011). MEXICO (Drake and Hottes 1951). PANAMA (Drake and Harris 1937). PUERTO RICO 


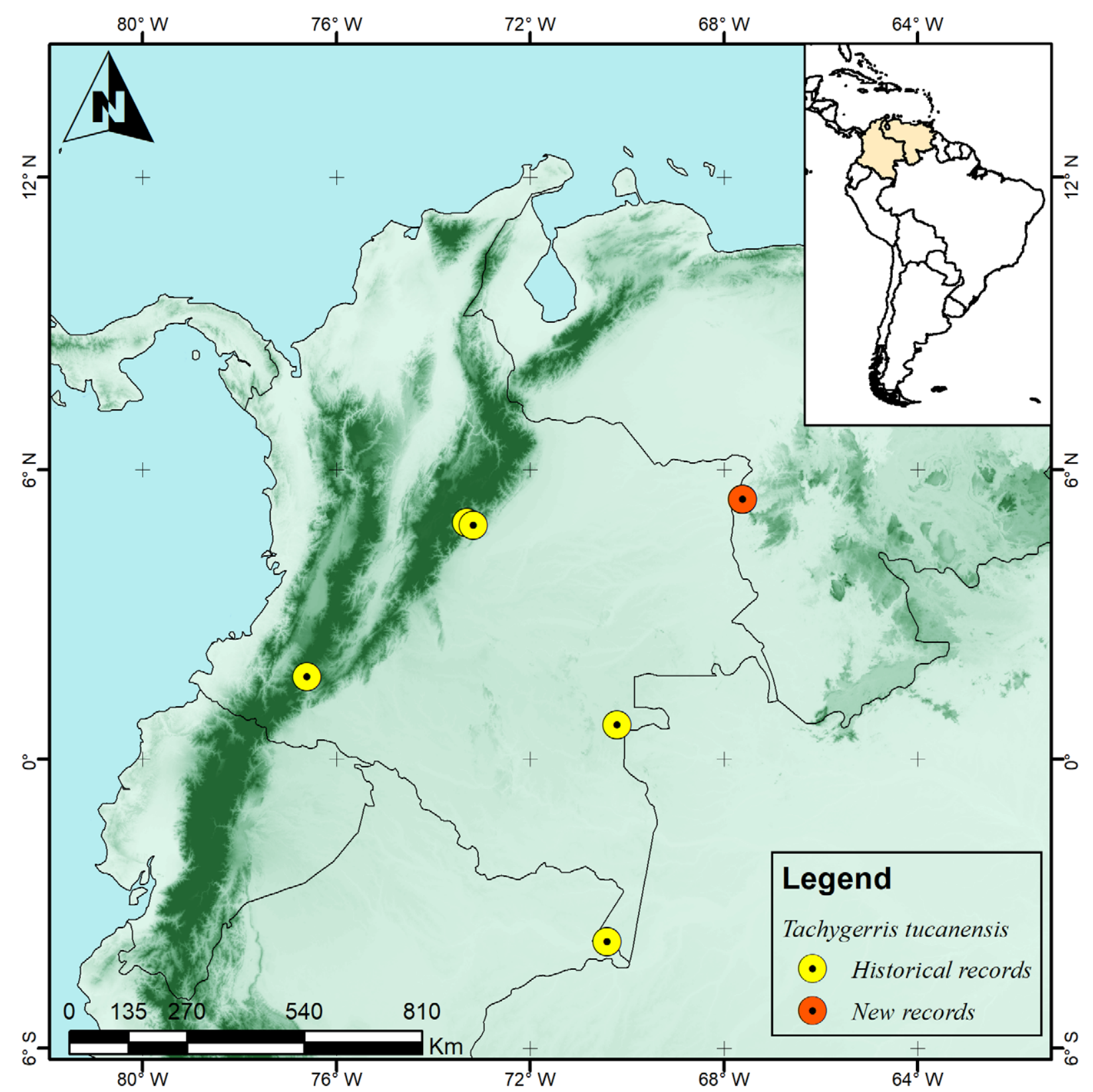

Figure 7. Historical and new records of Tachygerris tucanensis in the Americas.

(Drake and Harris 1937). VENEZUELA: Zulia (this work).

\section{Discussion}

This work presents new distribution records from Colombia and Venezuela for eight species. There is no checklist of semiaquatic bugs for the latter country, and the poor knowledge concerning the local Gerridae fauna is probably due to the lack of specialist taxonomists in the region (Moreira et al. 2016). Here, we contribute towards mitigating this shortfall by recording the following species from Venezuela for the first time: Brachymetra shawi, Limnogonus ignotus, Neogerris lotus, N. lubricus, Tachygerris tucanensis, Metrobates amblydonti, and Telmatometra ujhelyii. Although the Colombian fauna of the family is much better studied, we also present the first record from the country for Te. indentata.

The new records of Ta. tucanensis and Te. indentata constitute distribution expansions. The first was recently described from Vaupés department, Colombia (Morales and Castro 2013), then had its distribution expanded to the northwest (Boyacá department), west (Cauca department), and south (Amazonas department) (Mondragón-F. et al. 2017). Here, we extend its known distribution by about $600 \mathrm{~km}$ to the northeast, in the Venezuelan Amazonas state. The second species was heretofore known only from the type locality. We herein extend its distribution by about $2000 \mathrm{~km}$ to the northwest, in the Colombian Caldas department.

Furthermore, our records fill gaps in the geographic distributions of B. shawi, L. ignotus, N. lotus, N. lubricus, M. amblydonti, and Te. ujhelyii. For B. shawi, known 


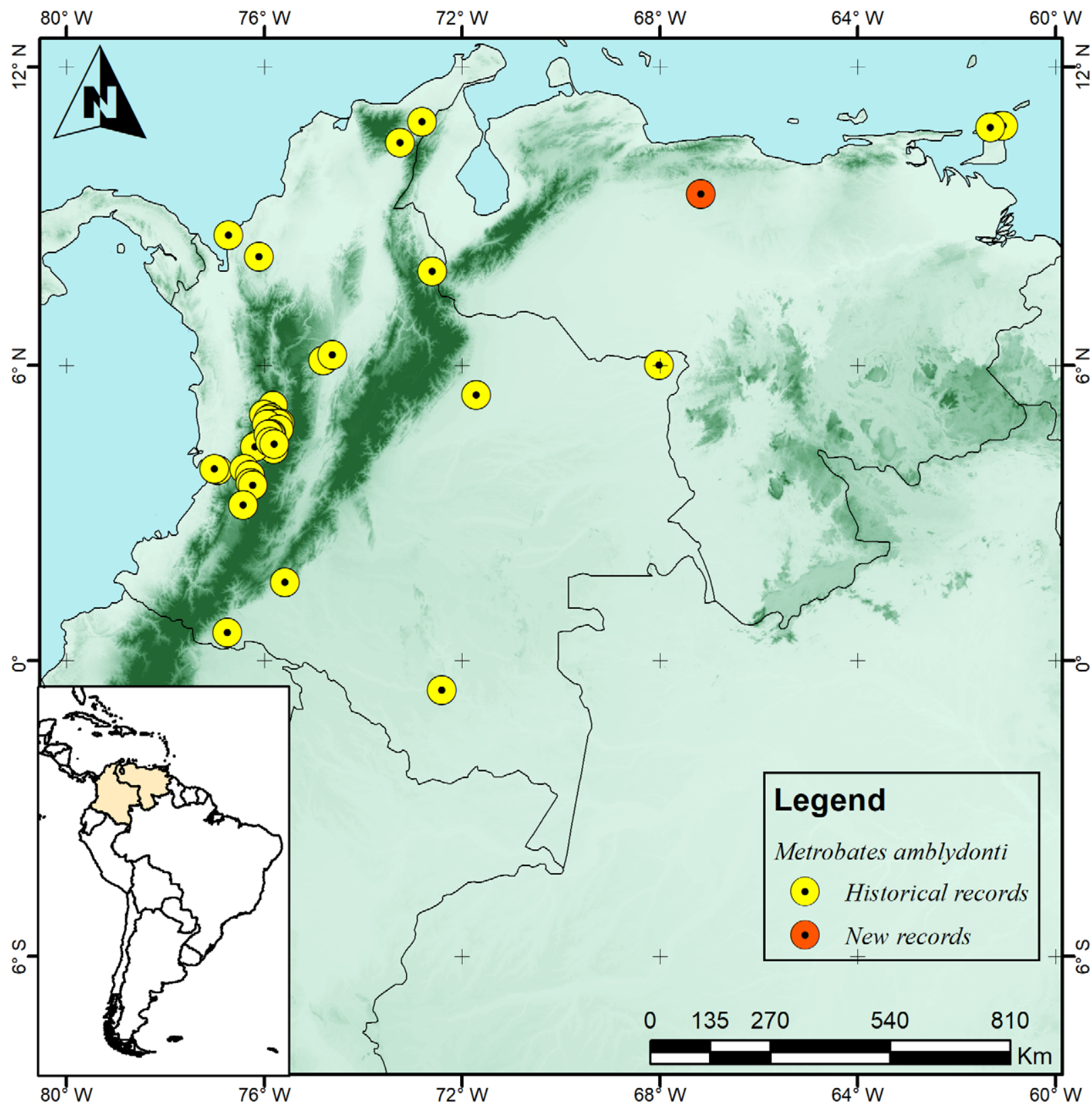

Figure 8. Historical and new records of Metrobates amblydonti in the Americas.

from Trinidad and Tobago and northern South America (Moreira 2021), the new record from Apure state, Venezuela, stands between previously known occurrences from Vaupés department, Colombia (Morales and Castro 2010), and the Caribbean island of Trinidad (Nieser and Alkins-Koo 1991). The new records of N. lotus and $N$. lubricus from Apure are similarly between previously known occurrences from Casanare department (Aristizábal-García 2017) and Trinidad (Nieser 1994). The distribution of the former is similar to that of $B$. shawi, but it extends further to the south, reaching central-western Brazil, whereas N. lubricus is the most widespread species of the genus in the Neotropics, occurring from Costa Rica to Argentina (Moreira 2021).

Additionally, the new record of Limnogonus ignotus from Apure lies between the known occurrences in Meta department, Colombia (Aristizábal-García 2002), and
Guyana (Drake and Harris 1934). The general distribution of this species ranges from northern South America to southern Uruguay (Moreira 2021). Metrobates amblydonti has a more restricted distribution. It was described from Trinidad island (Nieser 1993), then reported from several localities in Colombia (Aristizábal-García 2002, 2017; Posso and González 2008; Padilla-Gil 2013; Castro et al. 2018), leaving a gap in Venezuela that we now fill with our record from Guárico state. Finally, Te. ujhelyii has published records from Mexico and Puerto Rico (Drake and Harris 1937; Drake and Hottes 1951) to Ecuador (Buzzetti and Cianferoni 2011). The new record from Zulia state, Venezuela, lies between those from La Guajira department, Colombia, to the north (AristizábalGarcía 2002) and Norte de Santander department to the south (Aristizábal-García 2002). 


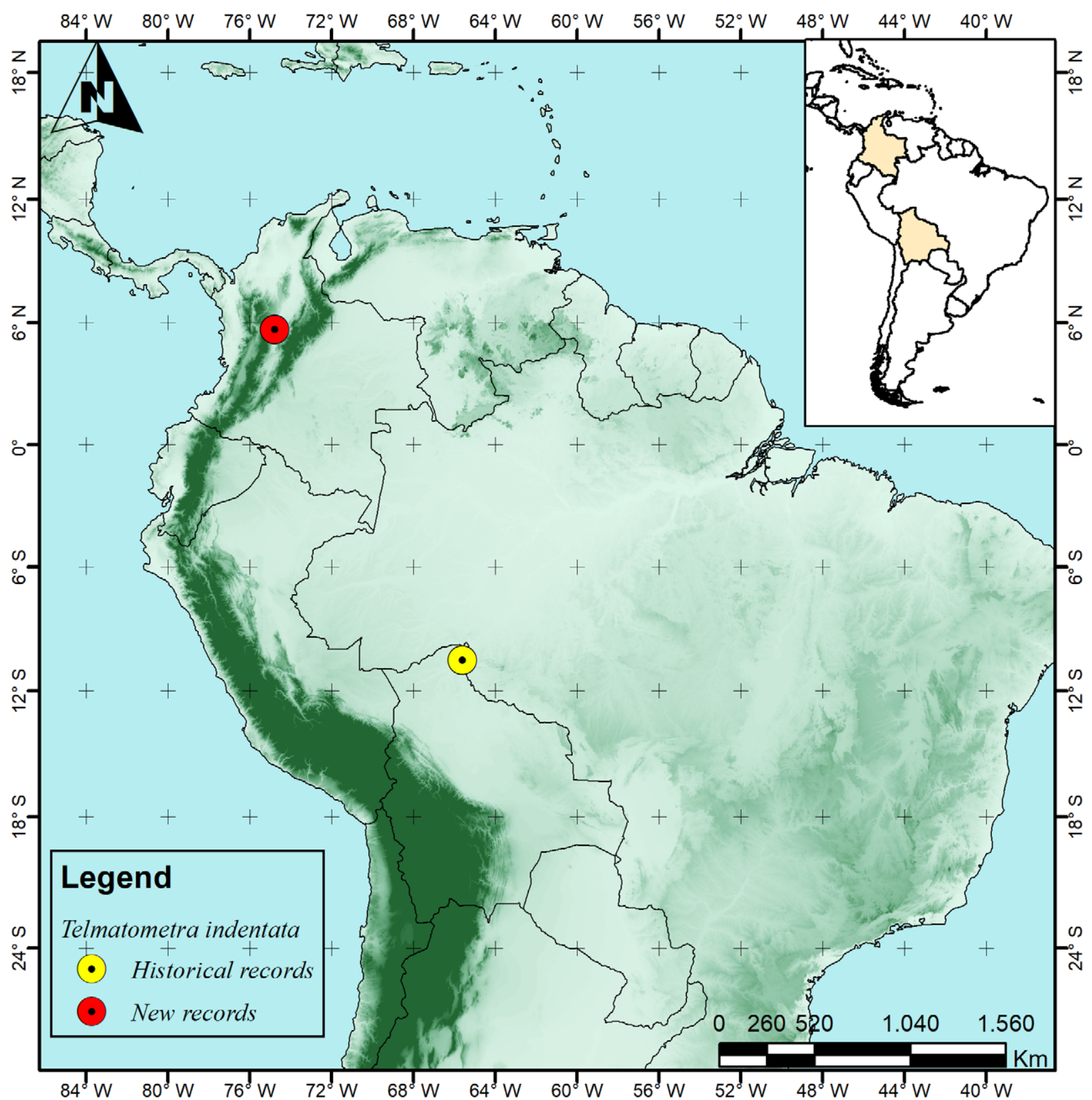

Figure 9. Historical and new records of Telmatometra indentata in the Americas.

\section{Acknowledgements}

We thank to Lorena García (Universidad del Quindío, Armenia, Colombia) and Camilo Llano (Universidad de Caldas, Manizales, Colombia). Isabelle R. S. Cordeiro (Instituto Oswaldo Cruz, Fundação Oswaldo Cruz, Rio de Janeiro, Brazil) and Carla F. B. Floriano (Universidade de São Paulo, Ribeirão Preto, Brazil, and Universidade Estadual Paulista "Júlio de Mesquita Filho", Assis, Brazil), for helping us with species identification. IM and SPMF thank the Dirección de Investigaciones from the Universidad Pedagógica y Tecnológica de Colombia (Tunja, Colombia) for the financial support provided for the project "La biodiversidad de Boyacá: complementación y síntesis a través de gradientes altitudinales e implicaciones de su incorporación en proyectos de apropiación social de conocimiento y de efectos de cambio climático, suscrito en el Grupo de Investigación Biodiversidad y Conservación, en el departamento de Boyacá, Código BPIN 2020000100003, Código SGI 2975. FFFM benefited from grants provided by Fundação Carlos Chagas Filho de Amparo à Pesquisa do Estado do Rio de Janeiro (\#E-26/201.066/2020, \#E-26/201.362/2021) and Conselho Nacional de Desenvolvimento Científico e Tecnológico (\#301942/2019-6).

\section{Authors' Contributions}

Conceptualization: IM. Data curation: FFFM. Formal analysis: SPM. Funding acquisition: IM, FFFM. Investigation: SPM. Methodology: IM. Project administration: IM, FFFM. Resources: IM. Supervision: IM. Validation: IM. Visualization: SPM. Writing - original draft: IM, SPM. Writing - review and editing: FFFM. 


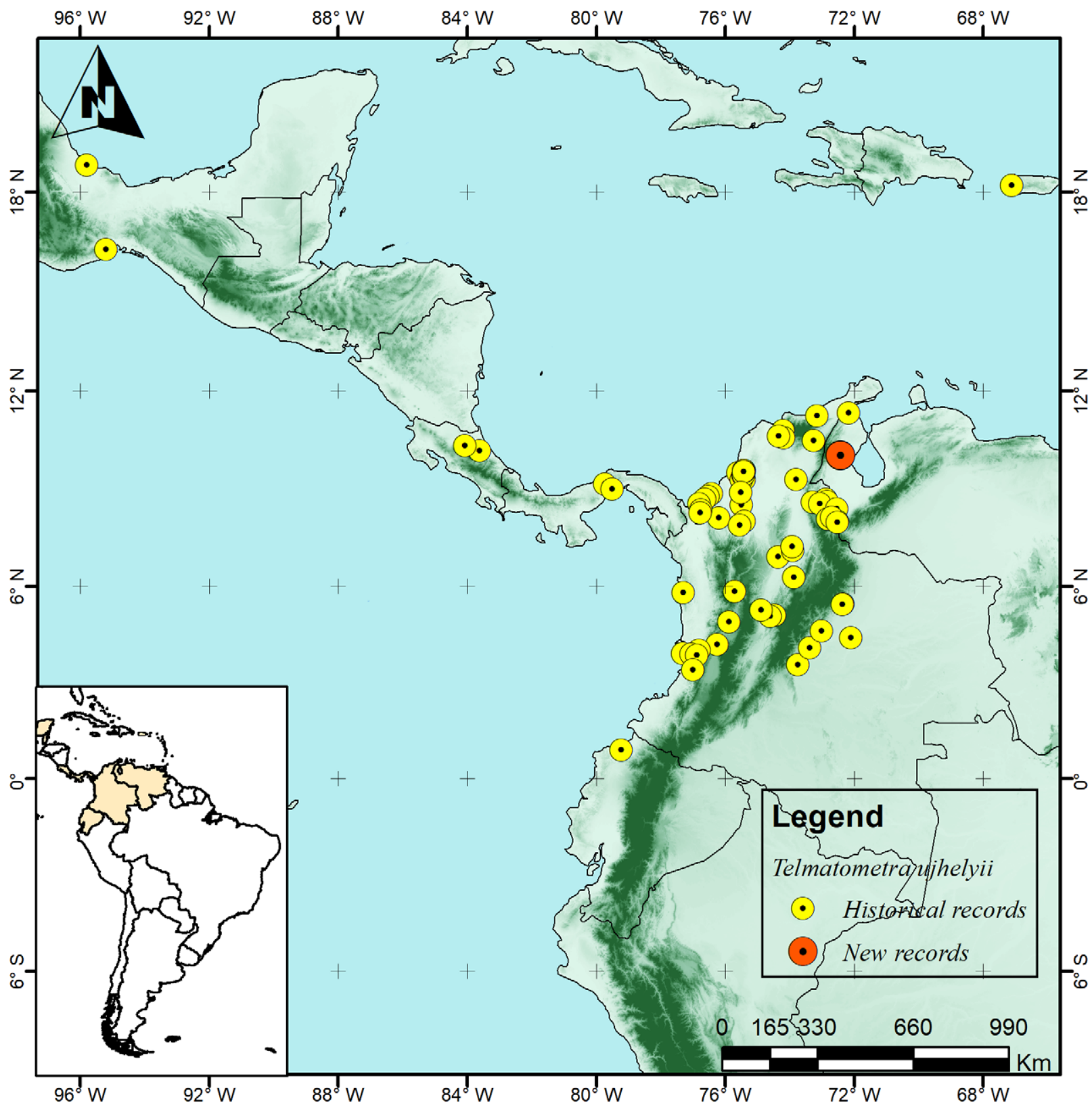

Figure 10. Historical and new records of Telmatometra ujhelyii in the Americas.

\section{References}

Andersen N (1982) The semiaquatic bugs (Hemiptera, Gerromorpha) Phylogeny, adaptations, biogeography and classification. Entomonograph 3: 1-455.

Aristizábal-García H (2002) Los hemípteros de la película superficial del agua en Colombia. Parte 1. Familia Gerridae. Academia Colombiana de Ciencias Exactas, Físicas y Naturales, Bogotá, 239 pp.

Aristizábal-García H (2017) Hemípteros Acuáticos y Semiacuáticos del Neotrópico. Academia Colombiana de Ciencias Exactas Físicas y Naturales, Bogotá, 984 pp.

Bachmann A (1962) El género Limnogonus en la Argentina (Hemiptera, Gerridae). Physis 23 (65): 152

Bachmann A (1964) Los Gerridae (Hemiptera) del Uruguay. Revista de la Sociedad Uruguaya de Entomología 6: 48.

Bachmann A (1966) Catálogo sistemático y clave para la determinación de las subfamilias, géneros y especies de las Gerridae de la República Argentina (Insecta, Hemiptera). Physis 26 (71): 207-218.

Buzzetti F, Cianferoni F (2011) Checklist of the Gerromorpha from Ecuador (Hemiptera: Heteroptera). Edessana, Beiträge zur Tax- onomie, Faunistik und Ökologie insbesondere tropischer Heteropteren 1: 117-125.

Castro-Vargas M, Morales I, Molano F (2018) A new species of Metrobates Uhler, 1871 (Hemiptera: Heteroptera: Gerridae) from Colombia. Zootaxa 4379 (4): 567-575. https://doi.org/10.11646/ zootaxa.4379.4.8

Cordeiro I (2017) Revisão taxonômica de Brachymetra Mayr, 1865 (Insecta: Heteroptera: Gerridae). Master thesis, Universidade Federal Rural do Rio de Janeiro, Rio de Janeiro, Brazil, 96 pp.

Cordeiro I, Moreira F (2015) New distributional data on aquatic and semiaquatic bugs (Hemiptera: Heteroptera: Gerromorpha \& Nepomorpha) from South America. Biodiversity Data Journal 3: e4913. https://doi.org/10.3897/BDJ.3.e4913

Drake C, Harris H (1934) The Gerrinae of the Western Hemisphere (Hemiptera). Annals of the Carnegie Museum 23: 179-241.

Drake C, Harris H (1935) Notes on American gerrids (Hemiptera). Arkiv för Zoologi 28B (2): 1-4.

Drake C, Harris H (1937) Notes on American Halobatinae (Gerridae, Hemiptera). Revista de Entomologia 7 (4): 357-362.

Drake C, Hottes F (1951) A new halobatinid from Mexico (Hemiptera; 
Gerridae). Proceedings of the Biological Society of Washington 64: 131-143.

Drake C, Roze J (1954) New Venezuelan Gerridae (Hemiptera). Proceedings of the Biological Society of Washington 67: 227-230.

Esaki T (1926) The water-striders of the subfamily Halobatinae in the Hungarian National Museum. Annales Musei Nationalis Hungarici 23: 117-164.

Floriano C, Moreira F, Bispo P (2017) New records of Gerromorpha (Insecta: Hemiptera: Heteroptera) from the Neotropical Region. Transactions of the American Entomological Society 143: 103 117. https://doi.org/10.3157/061.143.0202

Floriano C, Molano-Rendón F, Morales I, Moreira F, Bispo P (2019) Revision of the genus Platygerris White, 1883 (Hemiptera: Heteroptera: Gerridae), with descriptions of two species from Colombia. Insect Systematics \& Evolution 51 (4), 672-695. https://doi.org/10. 1163/1876312X-00002306

Hungerford H, Matsuda R (1957) Descriptions of two species of the genus Brachymetra (Gerridae, Hemiptera). Journal of Kansas Entomological Society 30: 19-25.

Kenaga E (1941) The genus Telmatometra Bergroth (Hemiptera-Gerridae), University of Kansas Science Bulletin 27 (9): 169-184.

Kuitert L (1942) Gerrinae in University of Kansas Collections. University of Kansas Science Bulletin 28 (7): 113-143.

Matsuda R (1961) Studies of relative growth in Gerridae (Hemiptera-Heteroptera). I-III. Annals of the Entomological Society of America 54: 578-598.

Mazzucconi S, Bachmann A (1993) Familia Gerridae (Heteroptera) estudio comparativo de las alas de las especies argentinas, chilenas y uruguayas. Revista de la Sociedad Entomológica Argentina 52 (1-4): 87-99.

Molano-Rendón F, Camacho-Pinzón D, Serrato-Hurtado C (2005) Gerridae (Heteroptera: Gerromorpha) de Colombia. Biota Colombiana 6 (2): 163-172.

Molano-Rendón F, Morales-Castaño I, Serrato-Hurtado C (2008) Clasificación y hábitats de Gerridae (Heteroptera-Gerromorpha) en Colombia. Acta Biológica Colombiana 13 (2): 41-60.

Molano-Rendón F, Mondragón S, Morales I (2017a) A new species of Rheumatobates Bergroth (Hemiptera: Heteroptera: Gerridae) from mangroves of the Colombian Caribbean region, new records, and a key to species recorded from the country. Zootaxa 4277 (2): 252-260. https://doi.org/10.11646/zootaxa.4277.2.5

Molano-Rendón F, Mondragón S, Morales I (2017b) Nueva especie y nuevos registros de Telmatometra (Hemiptera: Gerridae) en Colombia. Ciencia en Desarrollo 8 (1): 93-98.

Molano F, Mondragón-F P, Morales I (2018) Nuevas especies de chinches patinadoras (Hemiptera: Heteroptera: Gerridae) de Colombia. Acta Biológica Colombiana 23 (2): 179-188.

Mondragón-F S, Molano-Rendón F, Morales I (2017) Cinco nuevas especies de Tachygerris (Hemiptera: Gerridae: Gerrinae) y nuevos registros para Colombia. Caldasia 39 (2): 204-220. https://doi. org/10.1544 6/caldasia.v39n2.60603

Morales-Castaño I, Castro-Vargas M (2010) Nuevos registros y ampliación de distribución geográfica para especies de Gerridae (Insecta: Hemiptera) en Colombia. Acta Biológica Colombiana 15 (1): 271-280.

Morales-C I, Castro-Vargas M (2013) A new species and new records of Tachygerris Drake, 1957 (Hemiptera: Heteroptera: Gerridae) from Colombia. Zootaxa 3616: 277-283. https://oi.org/10.11646/ zootaxa.3616.3.5

Morales-Castaño I, Molano-Rendón F (2009) Revisión de los géneros Eurygerris y Tachygerris (Hemiptera: Tachygerrini) para la región neotropical. Revista Mexicana de Biodiversidad 80: 395410. https://doi.org/10.22201/ib.20078706e.2009.002.608

Morales-Castaño I, Rojas N, Jiménez-Ferbans L, Amat G, Devia N, Fernández F (2008) Insectos acuáticos. In: Rangel-Ch. JO (Ed) Estudio de Inventario de Fauna, Flora, Descripción Biofísica y Socioeconómica y Línea Base Ambiental de las Ciénagas de Mata de Palma y La Pachita. Convenio Instituto de Ciencias Naturales Universidad Nacional de Colombia, Corpocesar, Bogotá, Colombia, 169-187.

Moreira F (2015) The semiaquatic gerromorphans. In: Panizzi AR, Grazia J (Eds) True bugs (Heteroptera) of the Neotropics. Springer Science+Business Media, Dordrecht, Germany, 113-156. https:// doi.org/10.1007/978-94-017-9861-7_6

Moreira F (2021) Gerridae. In: Catálogo taxonômico da fauna do Brasil. Programa das Nações Unidas para o Desenvolvimento, Brasília, Brazil. https://fauna.jbrj.gov.br/fauna/faunadobrasil/2377. Accessed on: 2021-06-12.

Moreira F, Alecrim V, Ribeiro J, Nessimian J (2011) Identification key to the Gerridae (Insecta: Heteroptera: Gerromorpha) from the Amazon river floodplain, Brazil, with new records for the Brazilian Amazon. Zoologia 28 (2): 269-279. https://doi.org/10.1590/ S1984-46702011000200018

Moreira F (2016) Water bugs distributional database. https://sites.google. com/site/distributionaldatabase/. Accession date: 2017-06-12.

Moreno C, Molina W, Barbosa J, Moreira F (2018) Aquatic and semiaquatic bugs (Insecta, Hemiptera, Heteroptera) from Toluviejo Municipality, Sucre Department, Caribbean region of Colombia. Check List 14 (6): 985-1002. https://doi.org/10.15560/14.6.985

Motta F, Moreira F, Crumière A, Santos M, Khila A (2018) A new species of Rhagovelia Mayr, 1865 (Hemiptera: Heteroptera: Veliidae) from French Guiana, with new records of Gerromorpha from the country. Zootaxa 4433 (3): 520-530. https://doi.org/10.11646/zoo taxa.4433.3.7

Nieser N (1970) Gerridae of Suriname and the Amazon with additional records of other neotropical species. Studies on the fauna of Suriname and other Guyanas 12 (47): 94-138.

Nieser N (1993) Two new South American taxa of Metrobates (Heteroptera: Gerridae). Storkia 2: 21-25.

Nieser N (1994) A new species and a new status in Neogerris Matsumura (Heteroptera: Gerridae) with a key to American species. Storkia 3: 27-37

Nieser N, Alkins-Koo M (1991) The water bugs of Trinidad \& Tobago. Occasional Papers of the Zoology Department, University of the West Indies 9: 1-127.

Pacheco-Chaves B, Cordeiro I, Moreira F, Springer M (2018) The water striders (Hemiptera: Heteroptera: Gerridae) of Costa Rica: new species, checklist, and new records. Zootaxa 4471 (3): 493522. https://doi.org/10.11646/zootaxa.4471.3.4

Padilla Gil D N (2013) Nuevos registros y ampliación de la distribución de Heterópteros acuáticos en Colombia (Hemiptera, Heteroptera). Acta Biológica Colombiana 18 (2): 391-400.

Padilla-Gil D N (2017) Nuevos registros de Heteroptera (Hemiptera) acuáticos y semiacuáticos de Colombia. Biota Colombiana 17 (2): $39-46$.

Padilla-Gil D N (2019) Nuevas especies de Rhagovelia, Microvelia, Buenoa Registros nuevos de otros heterópteros de Colombia (Gerromorpha, Nepomorpha, Leptopodomorpha). Editorial Académica Española, Beau Bassin, 242 pp.

Posso C, González R (2008) Gerridae (Hemiptera: Heteroptera) del Museo Entomológico de la Universidad del Valle. Revista Colombiana de Entomología 34: 230-238.

QGIS.org (2020) QGIS Geographic Information System, Open Source Geospatial Foundation. https:/qgis.osgeo.org/. Accessed on: 2020-10-12.

Roback S, Nieser N (1974) Aquatic Hemiptera (Heteroptera) from the Llanos of Colombia. Proceedings of the Academy of Natural Sciences of Philadelphia 126: 29-49.

Shaw G (1933) A study of the genus Brachymetra (Hemiptera: Gerridae). University of the Kansas Science Bulletin 21: 221-233.

White F (1879) List of the Hemiptera collected in the Amazons by Prof. J. W. H. Trail, M.A., M.D., in the years 1873-1875, with descriptions of the new species. Transactions of the Entomological Society of London 1879 (4): 267-276. 